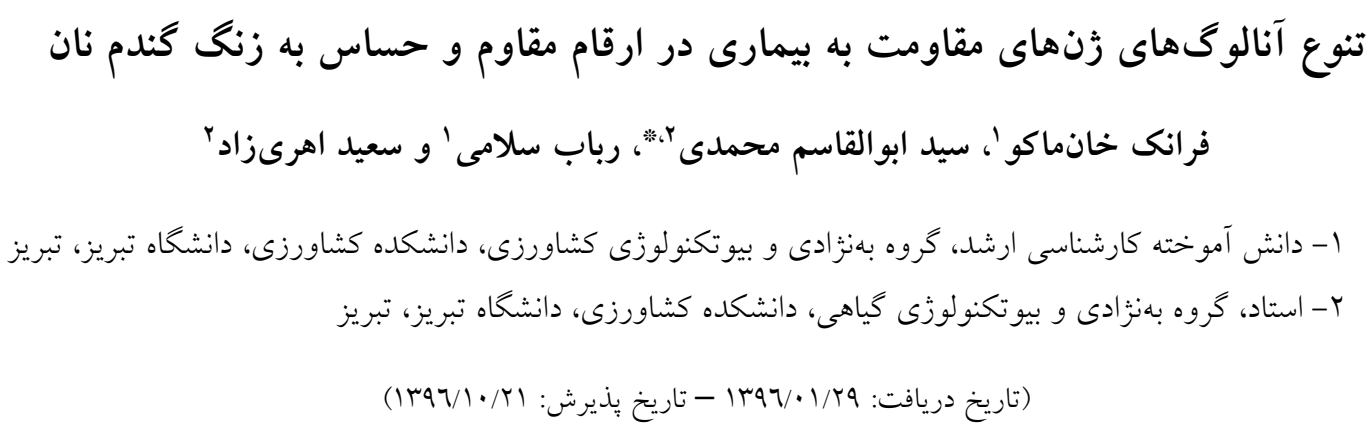

بيمارىهاى قارجى به خصوص زنخ هاى زرد و قهوهاى باعث كاهش عملكرد گُندم در ايران و جهان مىشوند. در اين مطالعه،

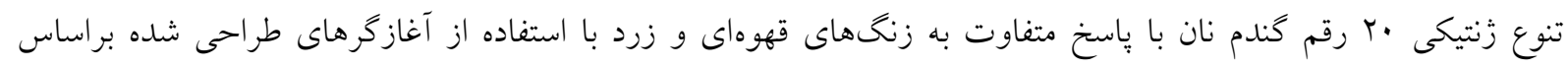

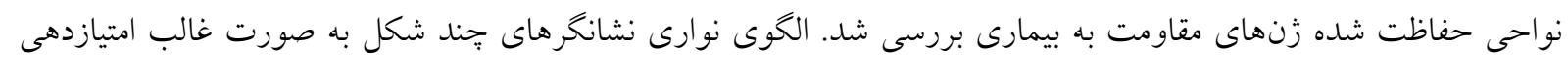

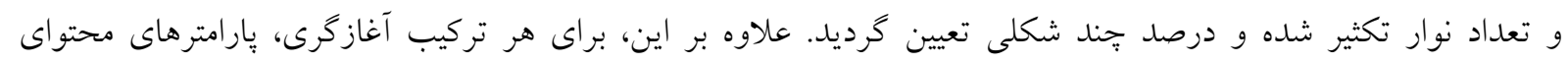

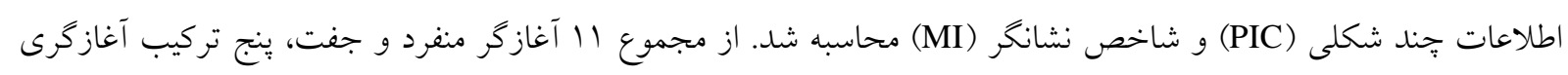

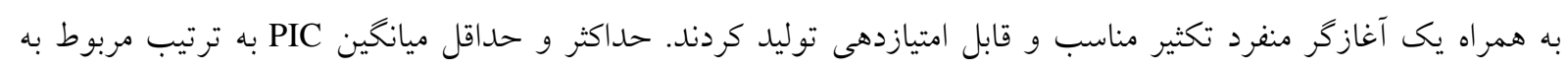

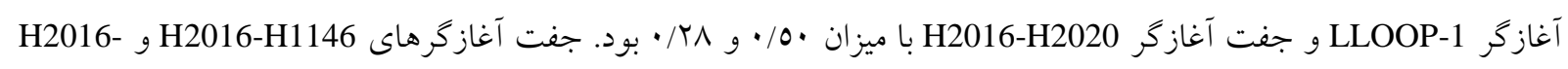

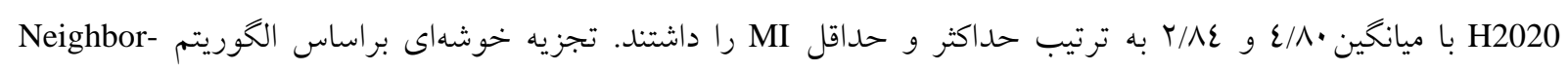

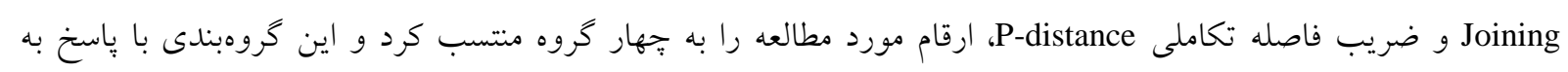

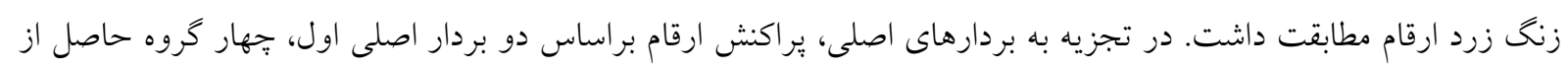
تجزيه خوشهاى را تأييد كرد. وازگَان كليدى: آنالو گهاى زنهاى مقاومت، تنوع زنتيكى، زنخ زرد، زنخ قهوهاى 
كياهان زراعى و كاهش خسارت ناشى از آنهاست. لازمه

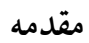

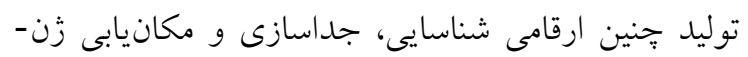

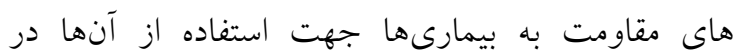
برنامههاى اصلاحى مى باشد.

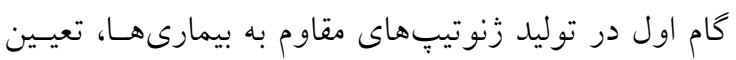

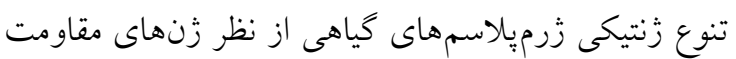

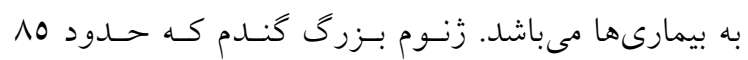

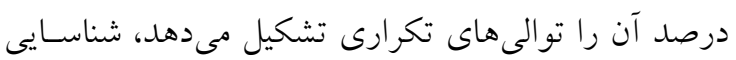
و همسانهسازى زنها را با مشكل مواجه مىسازد ( Gill et

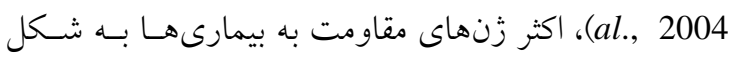

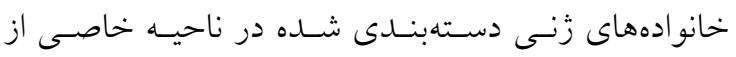

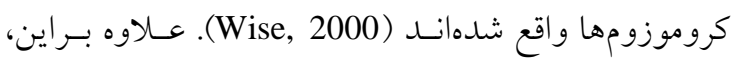

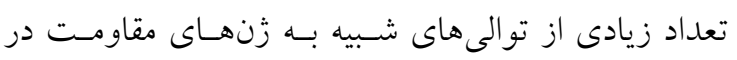

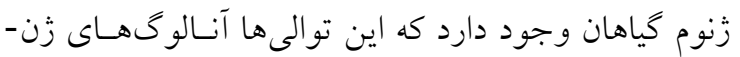

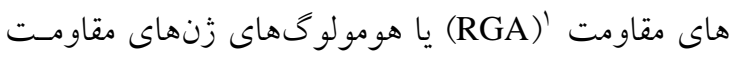

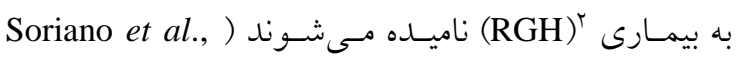
2005). تاكنون ينج گروه از زنهاى مقاومت به بيمارىهـا

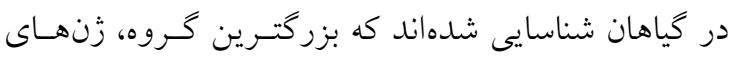

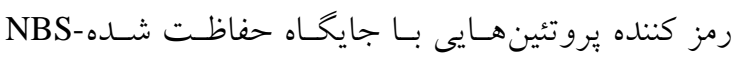

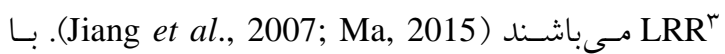
وجود اين منبع بزرگ از زنهــاى مقاومـت، تعـداد نسـبتاً

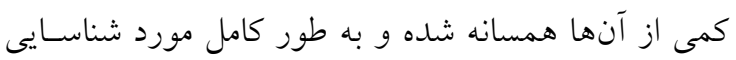

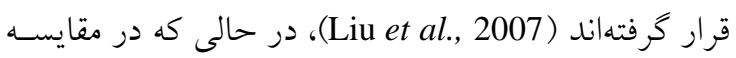

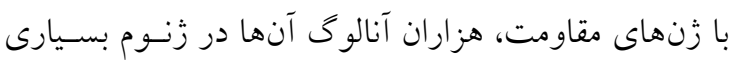

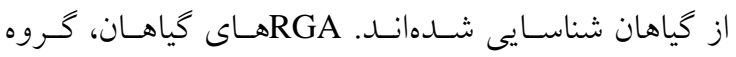
بزركى از زنهاى بالقوه مقاومت هستند كه داراى دامنـه و

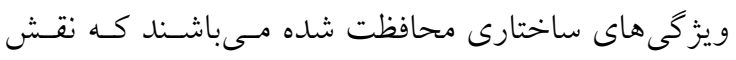
ويزّاى در تعاملات ميزبان و ياتوزن دارنـــ ( Sekhwal et

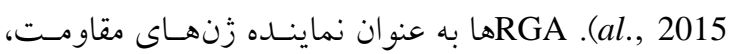

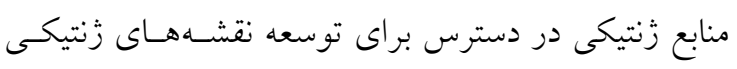

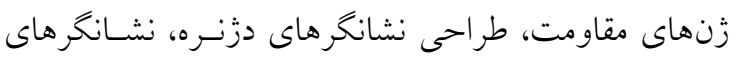

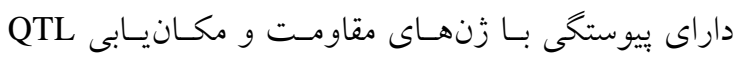

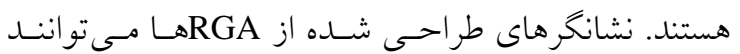

كُندم نان يكى از مهمترين كياهان زراعى و با ارزشترين

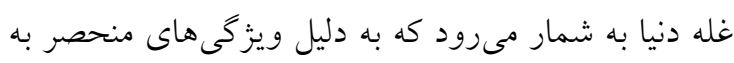

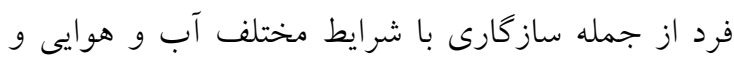

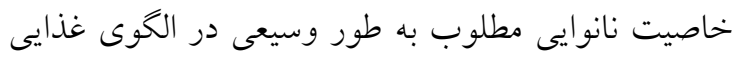

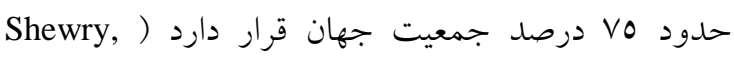
Maestra and Naranjo, 2000; 2009 سازمان خواروبار جهانى (FAO, 2017) در سال 17 r.

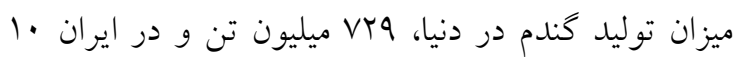
ميليون و . .7 هزار تن بوده است.

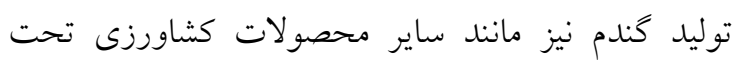

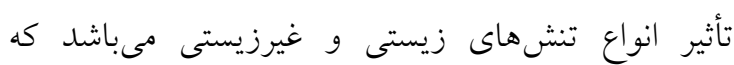

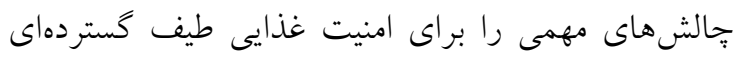

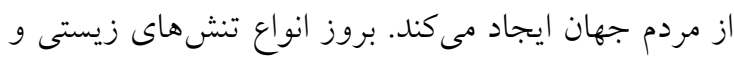
غيرزيستى يكى از عوامل مهم كاهش توليدات كشاورزى

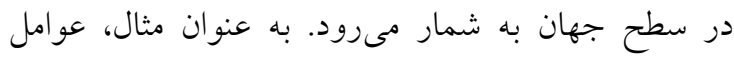
بيمارىزا به تنهايى موجب كاهش rا درصدى توليد كياهان زراعى در جهان مىباشند ( Rommens and Kishore, 2000 . ميزان كاهش محصول كُندم در اثر لثر تنشهاى زيستى و غيرزيستى نيز در تحقيقات مختلف به

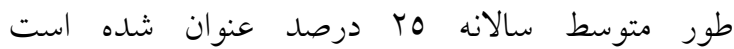

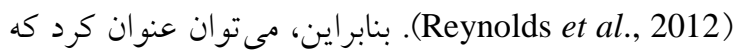
كاهش ميزان خسارت عوامل بيمارىزا مىتواند يكى از جالشهاى مهم در برنامهاى اصلاحى گندم در دنيا باشد.

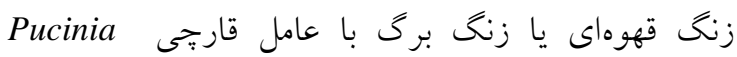
recondia f. sp. tritici جهان داشته و توليد گندم را تحت تأثير قرار مىدهد.

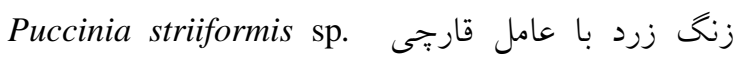
tritici

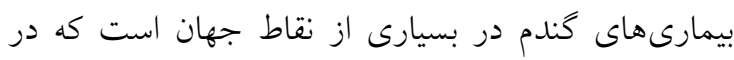

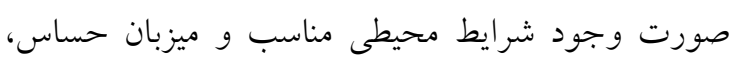

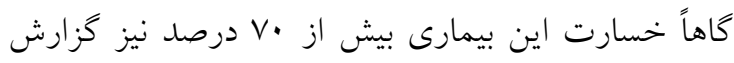
McIntosh et al., 1995; Chen, 2005; Cloutier ) است اسنان

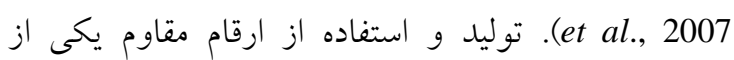

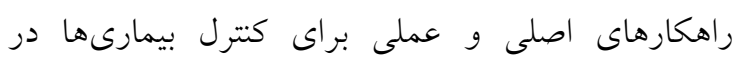


مواد گَياهى: مواد گياهى مورد مطالعه شامل ·r رقم گندم

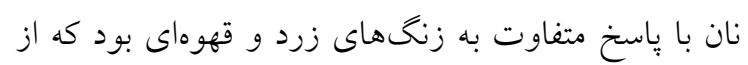

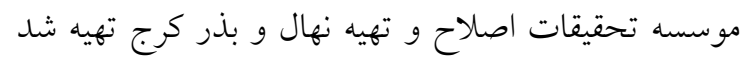

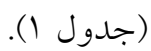
استخراج DNA زنومى و تكثير آنالوگهاى زنهاى ).

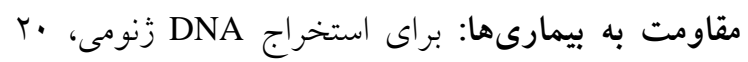

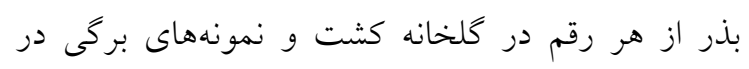

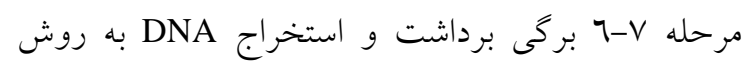
CTAB و كيفيت نمونههاى DNA استخراج شده به ترتيب بال

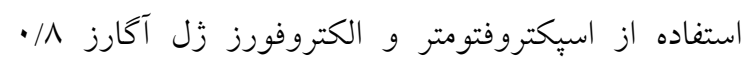

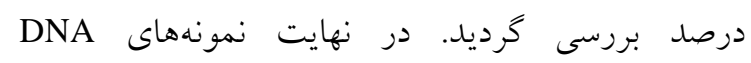

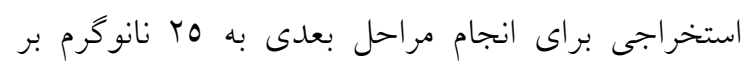
ميكروليتر رقيق شدند.

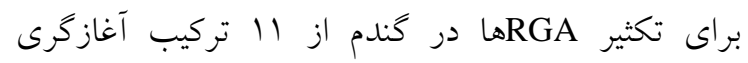
استفاده شد كه شش تركيب آغازگرى قطعاتى را در ارقام كندم مورد مطالعه تكثير كردند. تركيبات آغازكرى استفاده

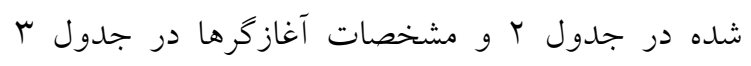

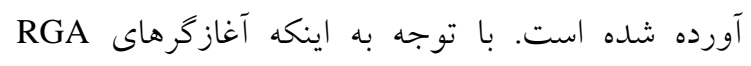

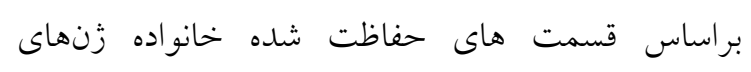

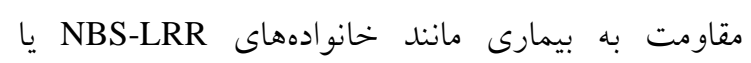
Kinase

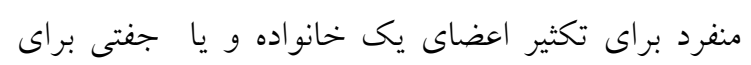
تكثير اعضاى دو خانو اده زنى استفاده شوند.

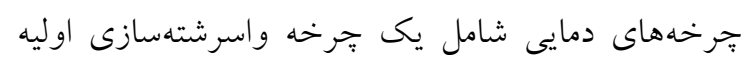

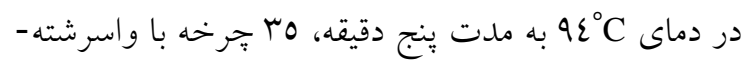

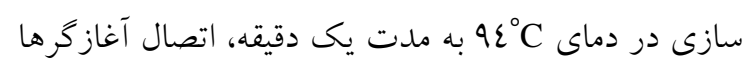
در دماى

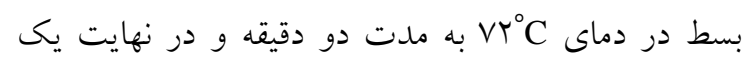
جرخه بسط نهايى در دماى VYC

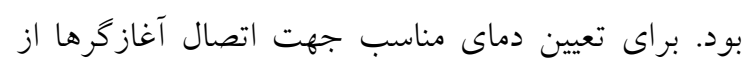
كراديان دمايى استفاده شد. محصولات تكثيرى با استفاده از زل آحَارز ب درصد تفكيك كرديد.
براى نقشهيابى و همسانهسازى زنهاى مقاومت در اهداف

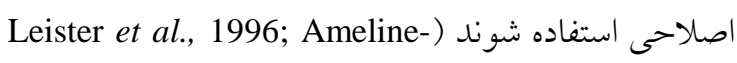
Torregrosa et al., 2008; Arya et al., 2014; Sekhwal .(et al., 2015; Kassa et al., 2017 آغازگرهاى دزنره، آغازگرهاى طراحى شده براساس توالى

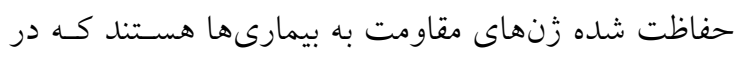

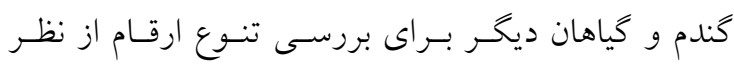

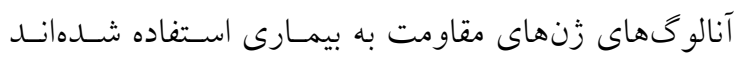
. (Mantovani et al., 2006; Wang et al., 2008)

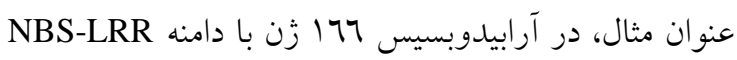

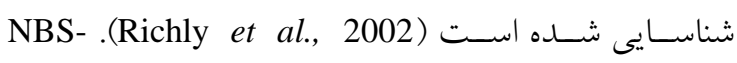

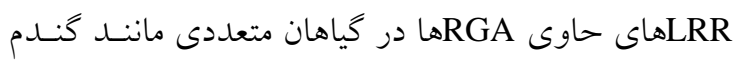
Jia et al., ) Aegilops tauschii ،(Bouktila et al., 2014) Ling et al., ) Triticum urartu ،(2013; Gu et al., 2015 2013; Gu et al., 2015 Wei et (Cheng et al., 2012; Wang et al., 2014) Fritz-Laylin et (al., 2013; Chen et al., 2015 (al., 2005; O’Toole et al., 2008; Singh et al., 2015 و سـورگوم (Cheng et al., 2010; Mace et al., 2014)

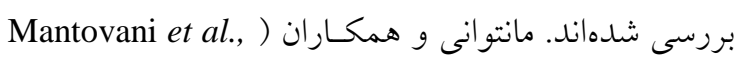

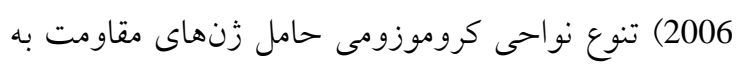

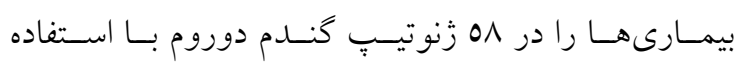

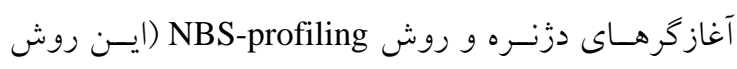

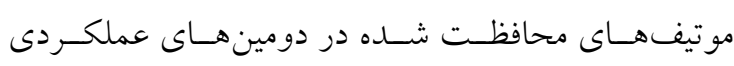

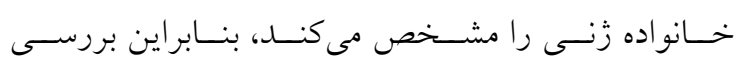
تنوعزنتيكى، در داخل يا اطراف زنهاى عملكـردى انجـام

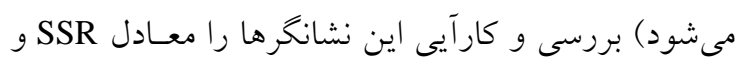
AFLP هدف اين مطالعه، بررسى تنوع زنتيكى ارقام مقاوم و

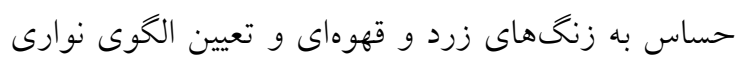

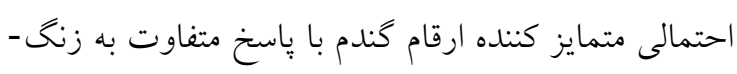

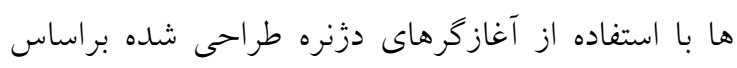
نواحى حفاظت شده دامنه زنهاى مقاومت به بيمارىها 


$$
\text { جدول 1- مشخصات ارقام گندم نان مورد مطالعه (تيب رشد و باسخ به زنخهاى زرد و قهوهاى). }
$$

Table 1. Characteristics of the studied bread wheat varieties (growth type, response to yellow and leaf rusts).

\begin{tabular}{|c|c|c|c|}
\hline \multicolumn{2}{|c|}{$\begin{array}{c}\text { ياسخ به زنيخ to rust } \\
\text { Response to }\end{array}$} & \multirow{2}{*}{$\begin{array}{c}\text { تيب رشد } \\
\text { Growth type }\end{array}$} & \multirow{2}{*}{$\begin{array}{c}\text { رقم } \\
\text { Variety }\end{array}$} \\
\hline زنخ قهوهاى & زنخ زرد & & \\
\hline Leaf rust & Yellow rust & & \\
\hline نيمه مقاوم & نيمه حساس & بهاره & زاگرس \\
\hline Semi Resistance & Semi susceptible & Spring & Zagros \\
\hline نيمه مقاوم & 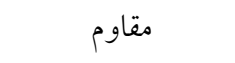 & بإييزه & Mv17 \\
\hline Semi Resistance & Resistance & Winter & tavis \\
\hline مقاوم & 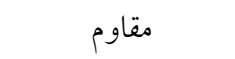 & بهاره & نيكنزاد \\
\hline Resistance & Resistance & Spring & NikNejad \\
\hline نيمه مقاوم & حساس & بهاره & فلات \\
\hline Semi resistance & Susceptible & Spring & Falat \\
\hline نيمه مقاوم & 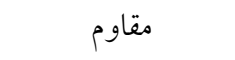 & بهاره & مرواريد \\
\hline Semi resistance & Resistance & Spring & Morvarid \\
\hline نيمه مقاوم & حساس & بهاره & اترى \\
\hline Semi resistance & Susceptible & Spring & Atrak \\
\hline نيمه مقاوم & حساس & بهاره & اينيا \\
\hline Semi resistance & Susceptible & Spring & Inia \\
\hline نيمه حساس & حساس & بهاره & كلستان \\
\hline Susceptible & Susceptible & Spring & Gholestan \\
\hline نيمه مقاوم & نيمه حساس & بهاره & مهلدوى \\
\hline Semi resistance & Semi susceptible & Spring & Mahdavi \\
\hline نيمه مقاوم & حساس & بهاره & تجن \\
\hline Semi resistance & Susceptible & Spring & Tajan \\
\hline حساس & حساس & بهاره & بولانى \\
\hline Susceptible & Susceptible & Spring & Bolani \\
\hline حساس & حساس & بينابين & شهريار \\
\hline Sensitive & Susceptible & Facultative & Shahryar \\
\hline حساس & حساس & بهاره & روشن \\
\hline Susceptible & Susceptible & Spring & Roshan \\
\hline حساس & حساس & بهاره & كرج' \\
\hline Susceptible & Susceptible & Spring & Karaj1 \\
\hline حساس & نيمه حساس & بينابين & كرجr \\
\hline Susceptible & Semi susceptible & Facultative & Karaj2 \\
\hline حساس & حساس & بهاره & شيراز \\
\hline Susceptible & Susceptible & Spring & Shiraz \\
\hline حساس & مقاوم & باييزه & كاسكوزن \\
\hline Susceptible & Resistant & Winter & Gascoigne \\
\hline حساس & مقاوم & ياييزه & گاسبارد \\
\hline Susceptible & Resistant & Winter & Gaspard \\
\hline حساس & مقاوم & بهاره & سايسون \\
\hline Susceptible & Resistant & Spring & Saison \\
\hline حساس & حساس & بينابين & قدس \\
\hline Susceptible & Susceptible & Facultative & Ghods \\
\hline
\end{tabular}




$$
\begin{aligned}
& \text { صورت يك و صفر انجام گرديد. براى تركيبات آغازگرى، }
\end{aligned}
$$

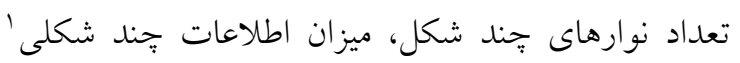

$$
\begin{aligned}
& \text { و شاخص نشانخر r (PIC) }
\end{aligned}
$$

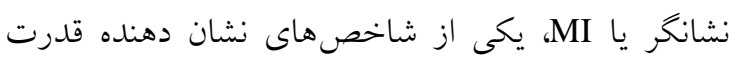

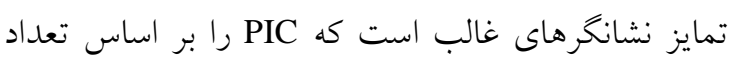

$$
\begin{aligned}
& \text { نوارهاى جند شكل نشانگر، موازنه مى كند. براى محاسبه }
\end{aligned}
$$

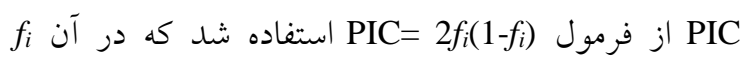

$$
\begin{aligned}
& \text { فراوانى نوار iام مىباشد. شاخص PIC براى هر نوار ابتدا } \\
& \text { محاسبه و سبس از PIC كليه نوارهاى يكى آغازگر ميانخين }
\end{aligned}
$$

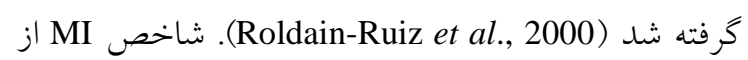

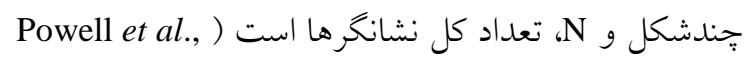
1996). براى گروهبندى ارقام، از تجزيه خوشهاى براساس

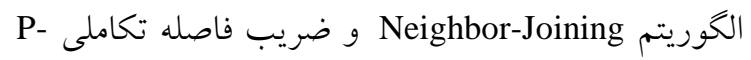
distance .(Tamura et al., 2011)

$$
\begin{aligned}
& \text { نتايج و بحث }
\end{aligned}
$$

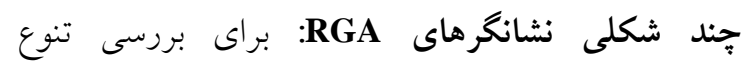

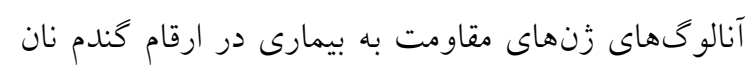

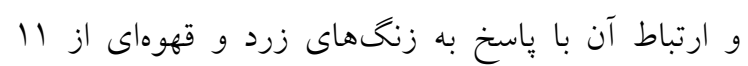

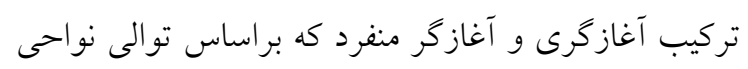

$$
\begin{aligned}
& \text { حفاظت شده زنهاى مقاومت به بيمارى كياهان با دامنه }
\end{aligned}
$$

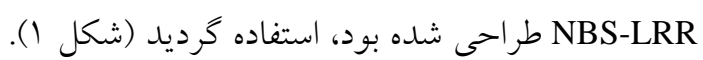

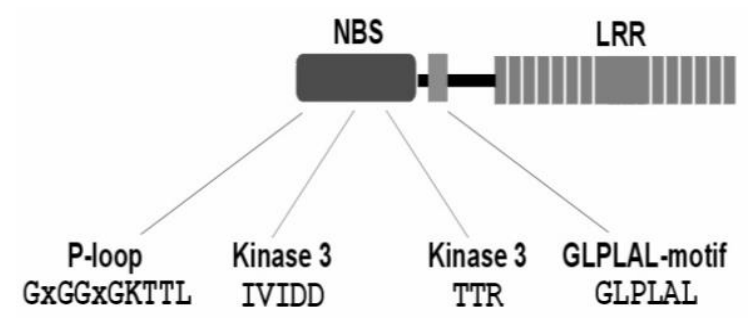

شكل ا-توالى اسيد آمينهاى دامنه حفاظت شده NBS در

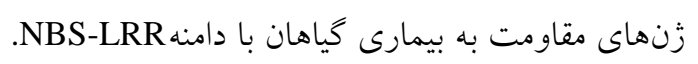

Figure 1. Amino acid sequence of conserved NBS domain in plant disease resistant genes with NBS-

$$
\text { LRR domain. }
$$

\begin{tabular}{|c|c|c|}
\hline آغازگر رفت & آغازگر معكوس & منشاء \\
\hline $\begin{array}{l}\text { Forward primer } \\
\qquad\left(5^{\prime}-3^{\prime}\right)\end{array}$ & $\begin{array}{l}\text { Reverse primer } \\
\qquad\left(3^{\prime}-5^{\prime}\right)\end{array}$ & Origin \\
\hline H2019 & H2027 & NBS \\
\hline H2019 & H2021 & NBS \\
\hline H2016 & H1146 & NBS \\
\hline H2016 & $\mathrm{H} 2020$ & NBS \\
\hline H2016 & H 2022 & NBS \\
\hline H2016 & $\mathrm{H} 2025$ & NBS \\
\hline H2016 & H2027 & NBS \\
\hline H1145 & H2023 & NBS \\
\hline H1145 & H2027 & NBS \\
\hline Cre3 gene 536-5: & $\begin{array}{l}\text { Cre3 gene } \\
1040-1060\end{array}$ & - \\
\hline Lloop-1 & Lloop-1 & NBS \\
\hline
\end{tabular}

1- Polymorphic information content 2- Marker index
جدول r - تركيبات آغازكرى استفاده شده براى تكثير آنالو گهاى زنهاى مقاومت به بيمارى در ارقام گُندم نان.

Table 2. Primer combinations used to amplify resistance gene analogs in bread wheat varieties

جدول بـ- توالى آغاز گرها و ناحيه تكثيرى توسط آنها.

Table 3. Primer sequences and their amplification region.

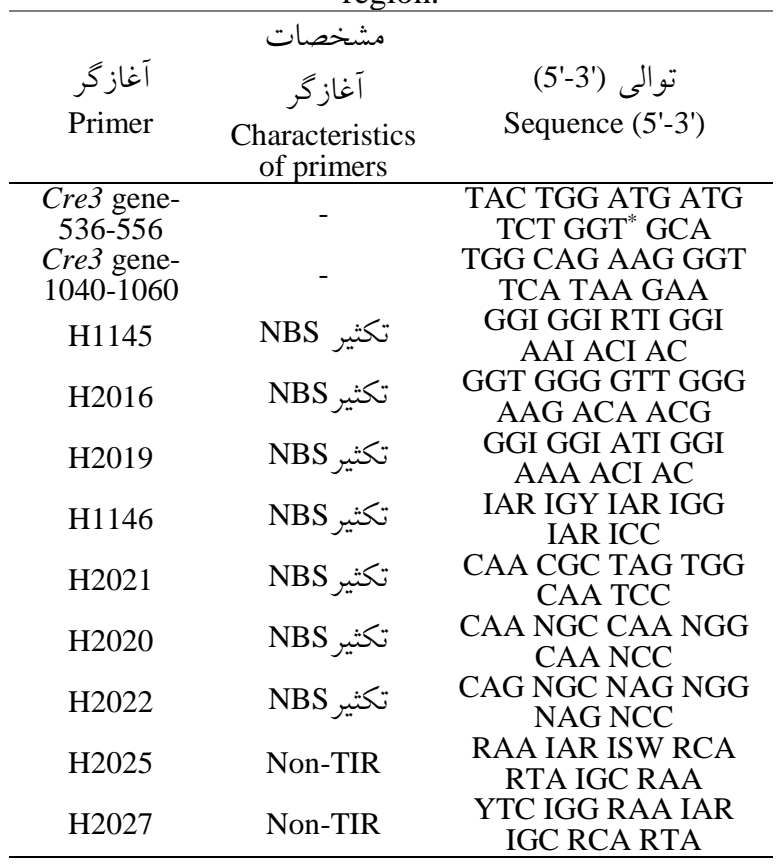

* علايم قراردادى به كاربرده شده براى بازها براساس استانداردهاى IUPAC

* Standard signs for bases based on IUPAC

R: Purine (A or $\mathrm{G}$ ); Y: Pyrimidine ( $\mathrm{T}$ or $\mathrm{C}$ ); W: A or T; $S$ : $G$ or $C ; M$ : A or C; K: G or T; H: A or T or C; B: $\mathrm{G}$ or C or T: V: G or A or C; D: G or A or T; $\mathrm{N}$ : $\mathrm{G}$ or $\mathrm{A}$ or $\mathrm{T}$ or $\mathrm{C}$; I: Inosine

تجزيه دادهها: هر نوار جند شكل در الكوى نوارى جفت

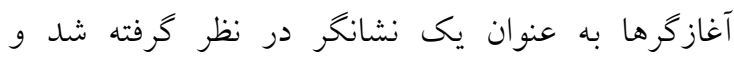

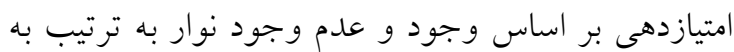


زنهاى مقاومت، نقش اساسى در مقاومت به ياتوزنها

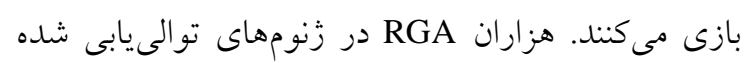

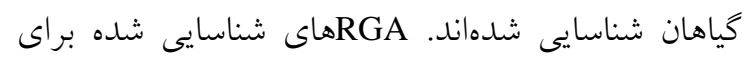

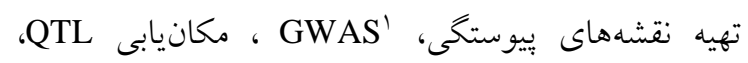

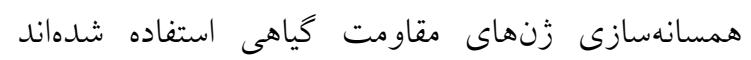

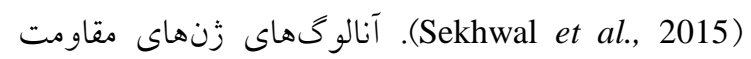
طيف گستردهاى از زنهاى مقاومت را شامل مى شوند. اما

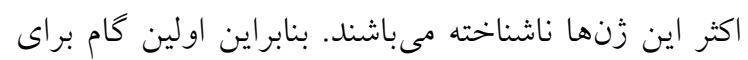

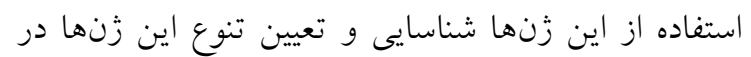

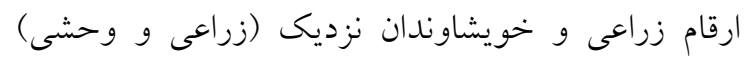
آنها مىباشد ( Ameline-Torregrosa et al., 2008; Arya

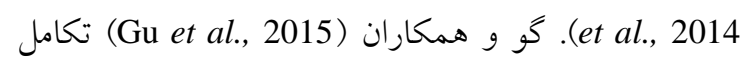
زنهاى NBS-LRR را در كندم نان و خوريشاوندان

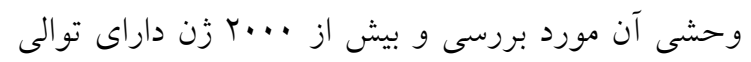
NBS

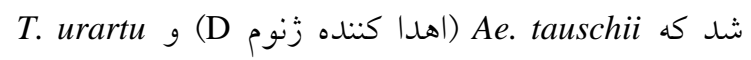

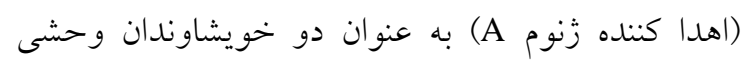

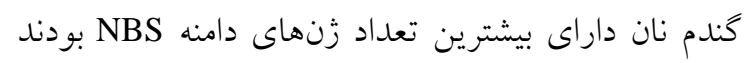
كه نشان دهنده وجود زنهاى داراى دامنه NBS در اجداد

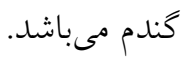

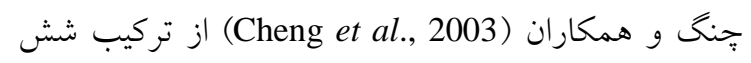

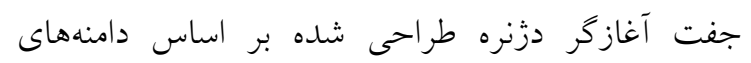

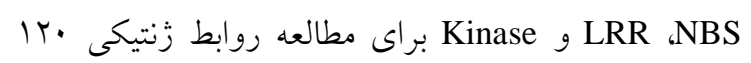
زنوتيب از سا جمعيت گندم ايمر (T. dicoccoides)

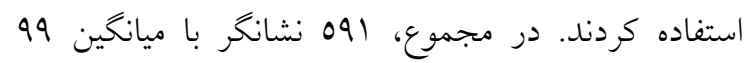

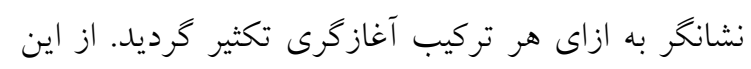

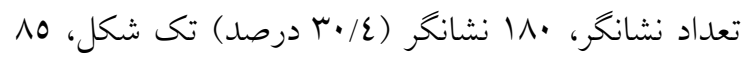

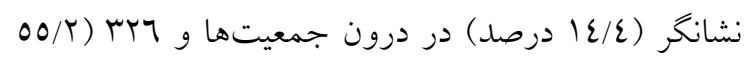

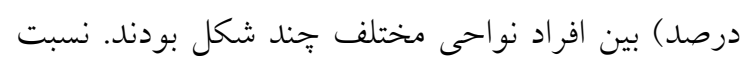

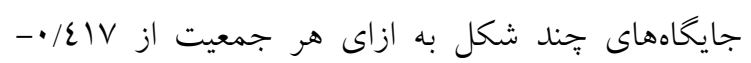

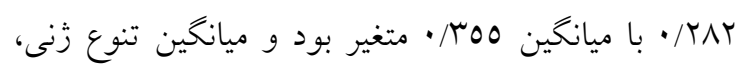

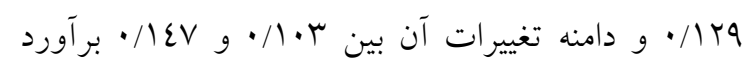

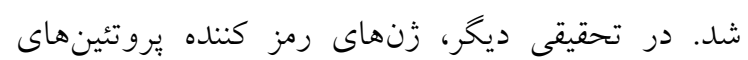

1- Genome wide association study
از 11 تركيب آغازكرى مورد استفاده، 7 تركيب داراى تكثير مناسب و قابل امتيازدهى بودند كه براى بررسى مردي

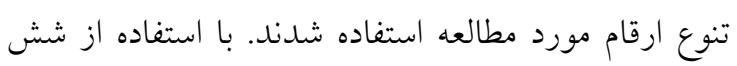

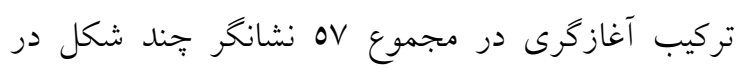

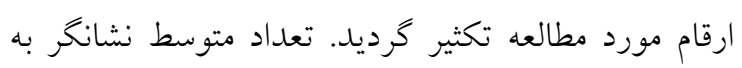

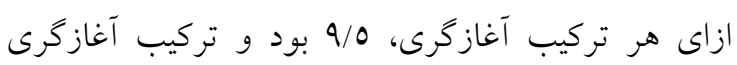

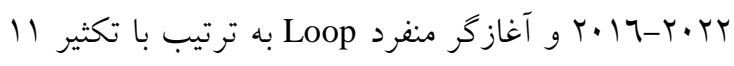
و 1 قطعه زنومى بيشترين و كمترين تعداد نشانكرهاى

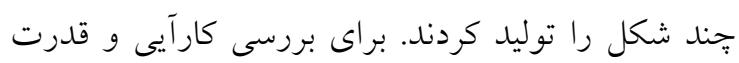

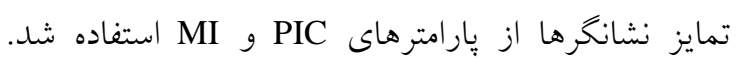
مقادير PIC براى نشانكر هاى RGA مورد مطالعه در دامنه

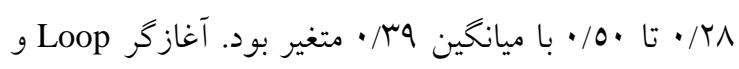

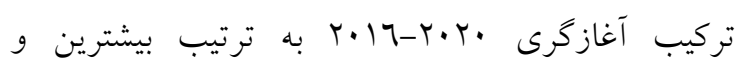
كمترين مقادير PIC را به خود اختصاص دادند. دامنه

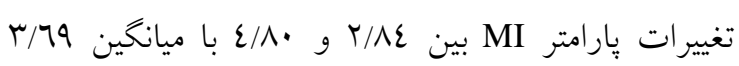

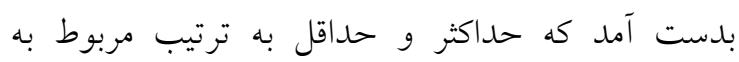
تركيبات آغازگرى

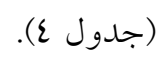

جدول ع- تعداد نشانخرهاى تكثير شده (N)، محتواى

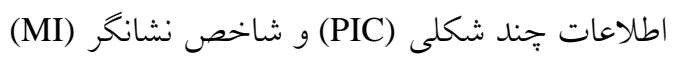
تركيبات آغاز گرهاى مورد استفاده در ارقام كُندم.

Table 4. Number of amplified markers (N), Polymorphic information content (PIC), Marker index (MI) of the primer combinations used in wheat varieties.

\begin{tabular}{cccc}
\hline Primer آغازگر & N & PIC & MI \\
\hline 2016-2027 & 9 & 0.36 & 3.24 \\
Loop & 8 & 0.50 & 4.00 \\
2016-1146 & 10 & 0.48 & 4.80 \\
2016-2020 & 10 & 0.28 & 2.84 \\
2016-2022 & 11 & 0.38 & 4.18 \\
2025-2016 & 9 & 0.34 & 3.06 \\
\hline ميانگ Mean & 9.5 & 0.39 & 3.69 \\
\hline
\end{tabular}

كَاهان مكانيسمهاى موثر توسعه يافتهاى براى شناسايى و

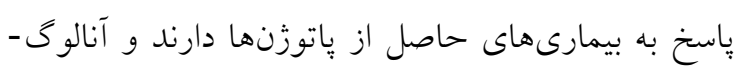

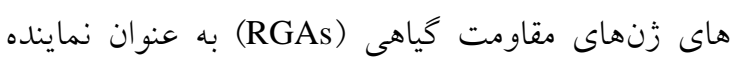


RGA رقم گندم ياكستانى با استفاده نشانخرهاى بررسى و ارتباط آنها با مقاومت ارقام به زنخ زرد مطالعه كرديد. سه تركيب آغازگرى مورد استفاده به ترتيب داراى درجه جند شكلى •ع، .0. و OV درصد بودند. در مجموع r نشانگر جّند شكل براى ارقام مورد مطالعه ايجاد و از اين نشانخرها براى شناسايى برخى از زنهاى مقاومت به

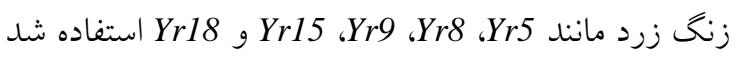

.(Tabassum et al., 2010)

\section{كروهبندى ارقام براساس دادهاى نشانخرهاى RGA} تجزيه خوشهاى: براى كروهبندى ارقام مورد مطالعه، از P- الكوريتم Neighbor-Joining و ضريب فاصله تكاملى distance استفاده گرديد. براساس اين گروهبندى، ارقام كندم مورد مطالعه به جهار كروه منتسب شدند (شكل Y).

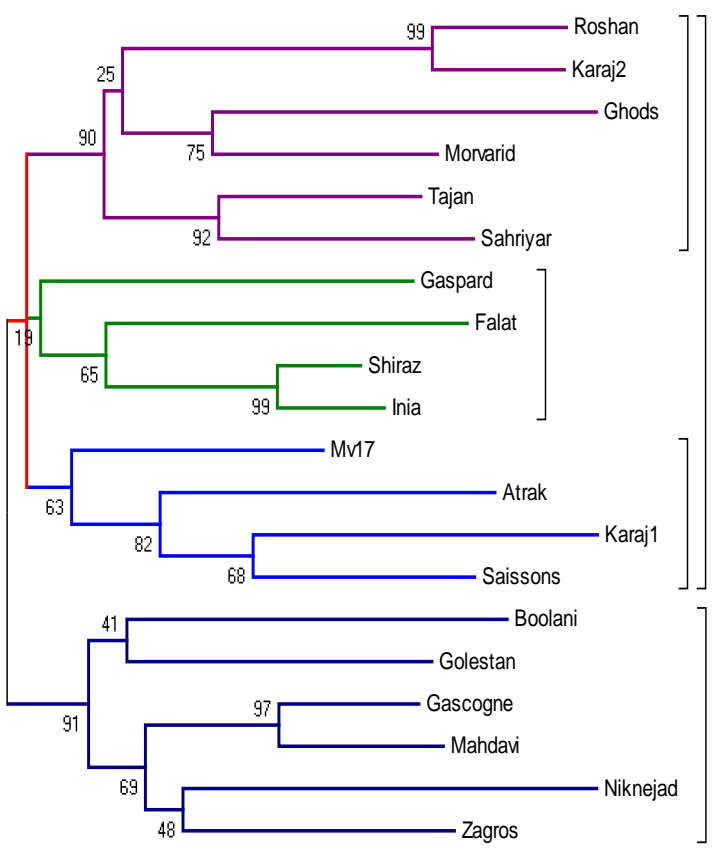

شكل r - گ گوهبندى ارقام گُندم نان براساس دادههاى Neighbor با استفاده از الكوريتم RGA شتانگرهاى

و وريب فاصله تكاملى Joining

Figure 2. Grouping of bread wheat varieties based on RGA markers data using Neighbor-Joining algorithm and evolutionary P-distance coefficient

در دندروگرام حاصل، ارقام روشن، كرجr، قدس و مروايد، تجن و شهريار در يك گروه قرار گرفتند. همه اين ارقام جز مرواريد حساس به زنخ زرد هستند. از نظر
مقاومت به بيمارى در زنوم T. urartu تجزيه و سوه آنالوى زنهاى مقاومت به بيمارى شناسايى شد كه از تعداد اين زنها در برنج ( •جع)، ذرت (7 •1) و سورگوم (YII) (بيشتر بود. در مقايسه با زنوم جو، نسبت زنهاى NBS-LRR ملاحظهاى بيشتر از جو (س// • درصد) به دست آمد (Ling et al., 2013) (اين تجزيه و تحليل ها نشان مىدهد كه گستره خاصى از آنالوگهاى زنهاى مقاومت در زنوم خويشاوندان وحشى كندم وجود دارد كه براى مقابله با جالشهاى امنيت غذايى و كشاورزى پايدار مورد نياز است. با وجود اين كه ارقام زراعى از نظر اكثر صفات داراى تنوع زنتيكى يايينى در مقايسه با خويشاوندان وحشى خود هستند، نتايج تحقيق ما و تحقيقات مشابه نشاندهنده تنوع قابل قبول از نظر RGA در ارقام Chen et al., ) زراعى كندم نان است. جّن و همكاران 1998) تنوع زنهاى مقاومت به زنخ زرد را در ارقام اصلاح شده گندم با استفاده از نشانگرهاى RGA بررسى و درصد جند شكلى را TV درصد گزارش كردند. آنها علت ڤِائين بودن تنوع آنالوگهاى زنهاى مقاومت در ارقام مورد مطالعه، يّايه زنتيكى محدود آنها بيان كردند كه از نظر زنهاى مقاومت به زنخ زرد داراى والد Habibzadeh et ) مشترى بودند. حبيبزاده و همكاران (al., 2007 براى بررسى تنوع زنهاى مقاومت به بيمارى در •ب رقم گندم خارجى و داخلى مقاوم و حساس به به بـ زنگ زرد، ينج جفت آغازگرRGA و با سه سيستم الكتروفورز استفاده كردند. با استفاده از سه جفت از ينج

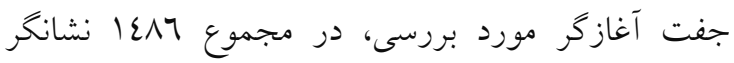
تكثير شد و درجه جهندشكلى سه جفت آغازگر بع، سب و هب درصد برآورد گرديد. براى مطالعه كارآيى نشانخرهاى دو شش رقم كندم نان تركيهاى مقاوم و حساس بـ

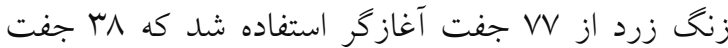
آغازگر بين ارقام مقاوم و حساس جند شكل و بقيه تك شكل بودند و تنها يك جفت آغازگر تكثير نشان نداد (Karakas et al., 2011). در مطالعهاى ديخر، تنوع زنتيكى ). 
سه بردار اول در مجموع Or/97 درصد از تغييرات

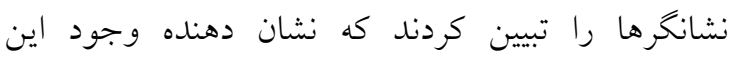
نشانگرها از نواحى زنومى خاص و كلاستر زنى مى باشد ردهد

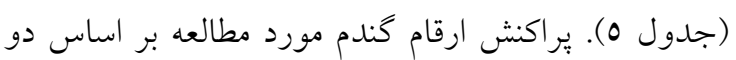
بردار اصلى اول در شكل مَ آورده شده است.

جدول 0- درصد واريانس تبيين شده توسط سه بردار اصلى اول در تجزيه به بردارهاى اصلى براساس داده-

$$
\text { هاى نشانگرهاى RGA. }
$$

Table 5. The percentage of variance explained by the three first principal components in principal coordinate analysis based on RGA marker data.

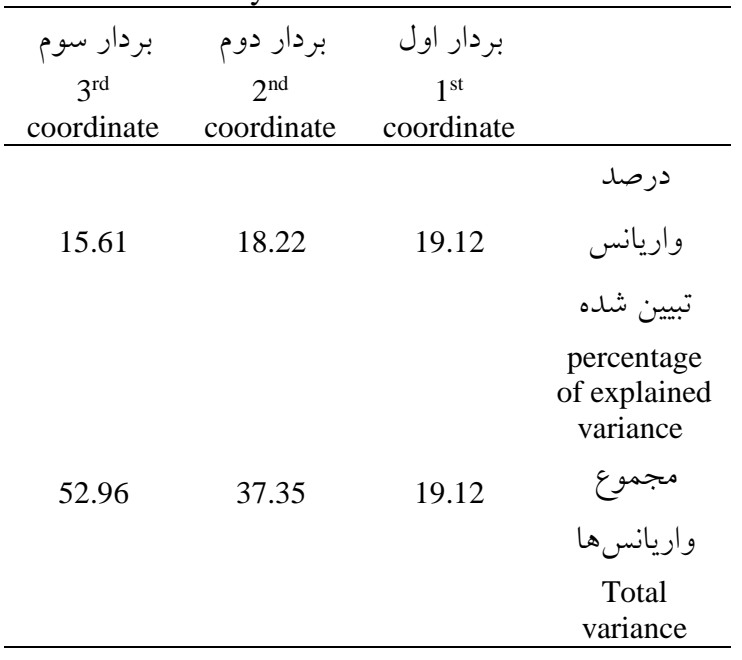

اين گروهبندى تا حد زياد با نتايج گروهبندى حاصل از تجزيه خوشهاى مطابقت داشت. به طورى كه در كروها

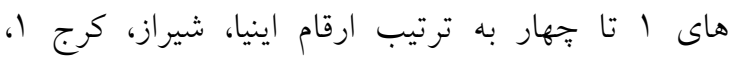

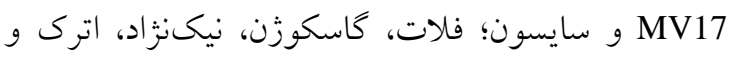
مرواريد؛ مهلدوى، شهريار، زاگرس، قدس، كلستان و تجن

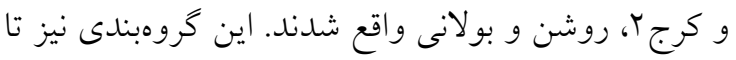
حدودى متناسب با پِاسخ به زنخ زرد ارقام بود. در سالهاى اخير با توجه به در دسترس بودن توالىهاى زنى، نشانكرهاى متعددى بر مبناى توالى هاى زنى جهت بررسى تغييرات و تنوع مولكول DNA طر احى شده است. اغلب اين نشانكرها براساس نواحى حفاظت شده توالى هاى زنى مىباشند و هدف استفاده از آنها شناسايى اثر عوامل زنتيكى مانند جهش در تغيير ساختار و در نتيجه عمل زن مىباشد.
ياسخ به زنخ قهوهاى، ارقام قدس، كرجr، روشن و

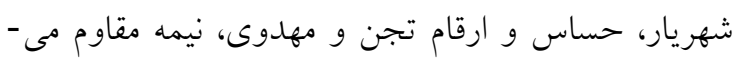

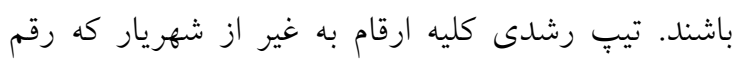

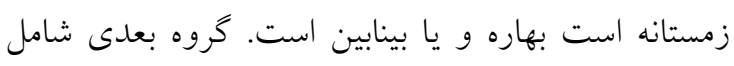

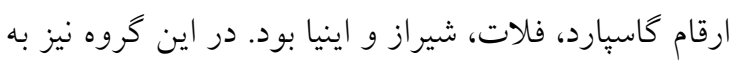

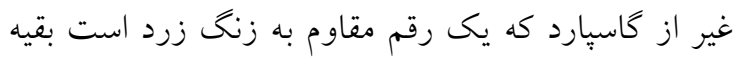

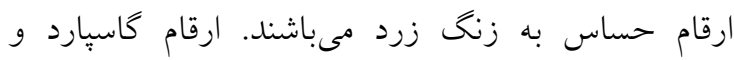

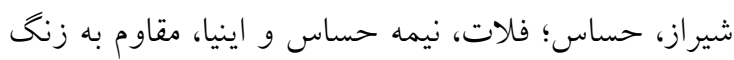
قهوهاى هستند. جهار رقم MV17، اترك، كرج 1 و و

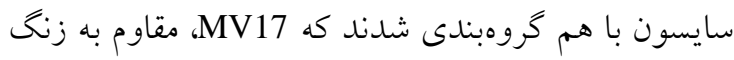

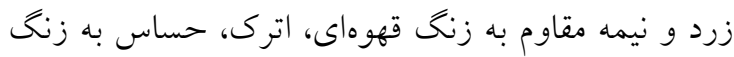

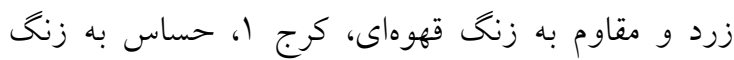

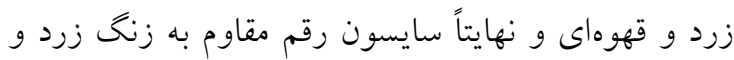
حساس به زنخ قهوهاى مىباشد. كروه آخر شامل بولانى، كلستان، كاسكوزن، نيكنزاد و زاكرس بود كه بولانى و كلستان، حساس، مرواريد و نيكنزاد، نيمه حساس و و كاسكوزن و نيكنزاد مقاوم به زنخ زرد هستند. از نظر ياسخ به زنخ قهوهاى، بولانى و كاسكوزن حساس و بقيه

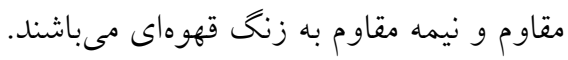

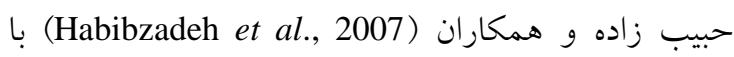

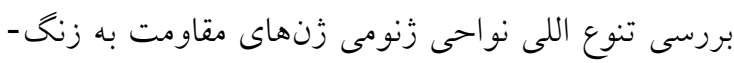

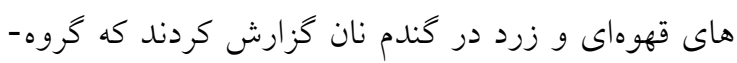

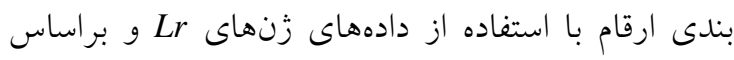

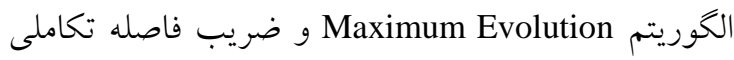

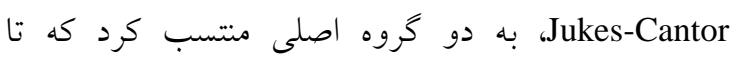

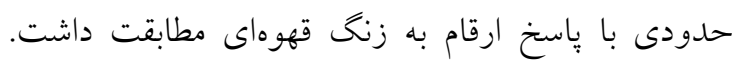

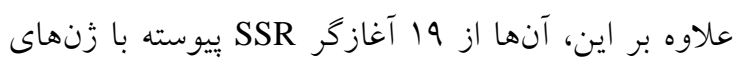
نr هاى نشانكرهاى SSR با استفاده از الكوريتم Maximum Evolution و ضريب فاصله تكاملى Jukes-Cantor را به جهار كروه منتسب كرد كه اين كروهبندى تاحدودى

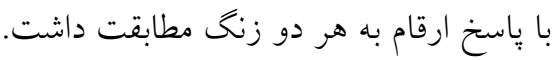
تجزيه به بردارهاى اصلى (PCoA): تجزيه به بردارهاى

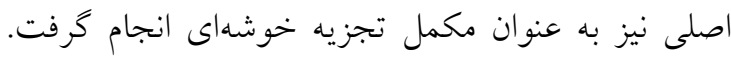



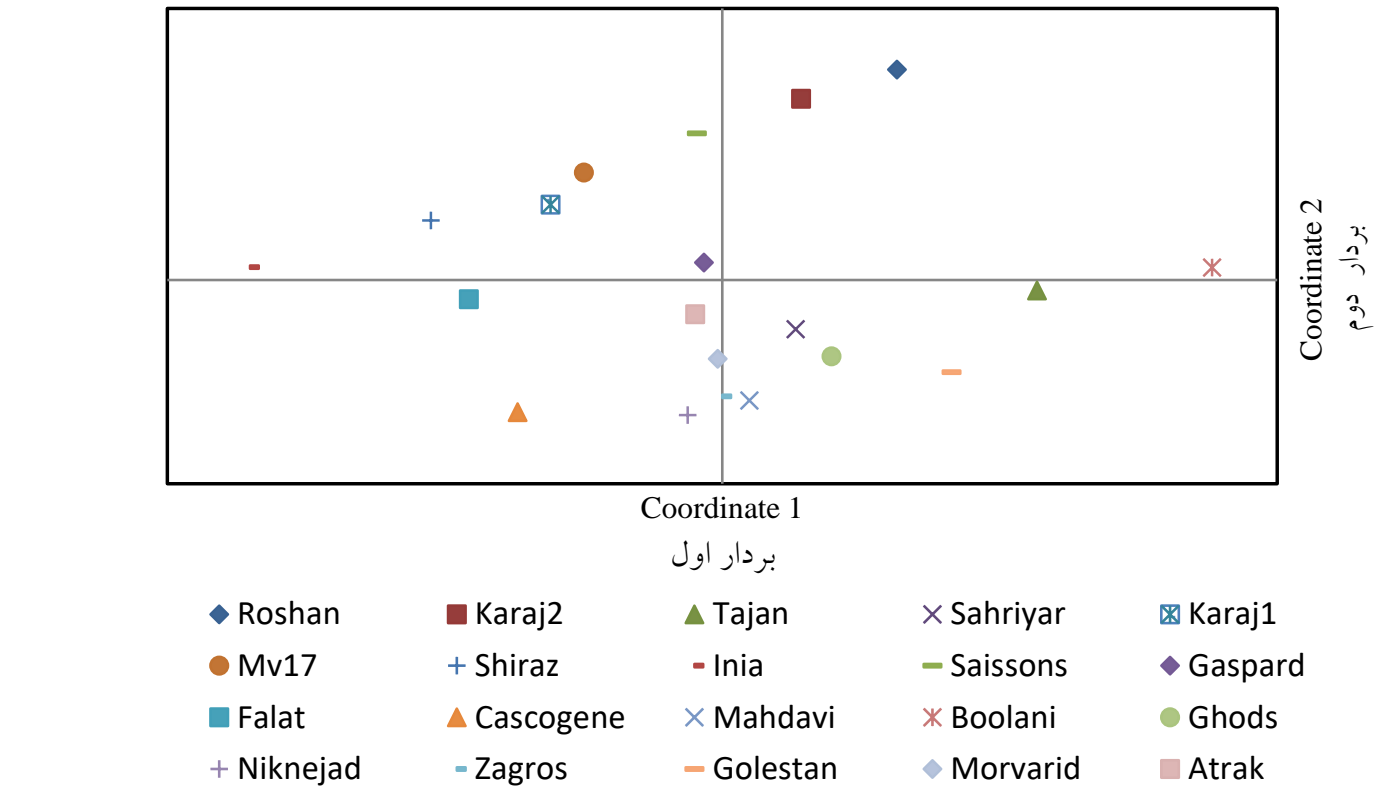

شGA شكل س- نمودار ير اكنش ارقام كندم نان براساس دو بردار اول حاصل از تجزيه به بردارهاى با استفاده از دادههاى

Figure 3. Distribution plot of bread wheat varieties based on two first principal coordinates resulting for principal coordinate analysis using RGA data

$$
\begin{aligned}
& \text { استفاده قرار گيرند. با توجه به اينكه اين نواحى در كليه } \\
& \text { خانو ادهاى زنى حفاظت شده هستند، بنابر اين آغازگر هاى } \\
& \text { طراحى شده در كليه گونهاى گياهى قابل استفاده مى - } \\
& \text { باشند. } \\
& \text { سياسگزارى } \\
& \text { اين تحقيق با حمايت مالى قطب علمى اصلاح مولكولى } \\
& \text { غلات دانشعاه تبريز انجام شده است. }
\end{aligned}
$$

\section{References}

Ameline-Torregrosa, C., Wang, B.B., O'Bleness, M.S., Deshpande, S., Zhu, H., Roe, B., Young, N.D. and Cannon, S.B. (2008). Identification and characterization of nucleotide-binding siteleucine-rich repeat genes in the model plant Medicago truncatula. Plant Physiolgy, 146: 5-21.

Arya, P., Kumar, G., Acharya, V. and Singh, A.K. (2014). Genome-wide identification and expression analysis of NBS-encoding genes in Malus x domestica and expansion of NBS genes family in Rosaceae. PLoS ONE, 9: e107987.

Bouktila, D., Khalfallah, Y., Habachi-Houimli, Y., Mezghani-Khemakhem, M., Makni, M. and Makni, H. (2014). Large-scale analysis of NBS domain-encoding resistance gene analogs in Triticeae. Genetics and Molecular Biology, 37: 598-610.

Chen, X.M. (2005). Epidemiology and control of stripe rust (Puccinia striiformisf. sp. tritici) on wheat. Canadian. Journal of Plant Pathology, 27: 314-337.

Chen, J.Y., Huang, J.Q., Li, N.Y., Ma, X.F., Wang, J.L., Liu, C., Liu, Y.F., Liang, Y., Bao, Y.M. and Dai, X.F. (2015). Genome-wide analysis of the gene families of resistance gene analogues in cotton and their response to Verticillium wilt. BMC Plant Biology, 148: 1-15. 
Chen, X.M., Line, R.F. and Leung, H. (1998). Genome scanning for resistance gene analogue in rice, barley and wheat by high solution electrophoresis. Theoretical and Applied Genetics, 97: 345355.

Cheng, X., Jiang, H., Zhao, Y., Qian, Y., Zhu, S. and Cheng, B. (2010). A genomic analysis of disease-resistance genes encoding nucleotide binding sites in Sorghum bicolor. Genetics and Molecular Biology, 33: 292-297.

Cheng, Y., Li, X., Jiang, H., Ma, W., Miao, W., Yamada, T. and Zhang, M. (2012). Systematic analysis and comparison of nucleotide-binding site disease resistance genes in maize. The FEBS Journal, 279: 2431-2443.

Cheng, J.P., Yan, J. and Dahan, A. (2003). Disease resistance gene analog polymorphism of wild emmer wheat population, Tenth International Wheat Genetics Symposium. Italy 1-6 September 2003.

Cloutier, S., Mccallum, B.D., Loutre, C., Banks, T.W., Wicker, T., Feuillet, C., Keller, B. and Jordan, M.C. (2007). Leaf rust resistance gene Lr1 isolated from bread wheat (Triticum aestivum L.) is a member of the large psr567 gene family. Plant Molecular Biology, 65: 93-106.

FAO. (2017). FAO STAT. www.faostat.Fao.org.

Fritz-Laylin, L.K., Krishnamurthy, N., Tor, M., Sjolander, K.V. and Jones, J.D. (2005). Phylogenomic analysis of the receptor-like proteins of rice and Arabidopsis. Plant Physiology, 138: 611-623.

Gill, B.S., Appels, R., Botha-Oberholster, A.M., Buell, C.R., Bennetzen, J.L., Chalhoub, B., Chumley, F., Dvorak, J., Iwanaga, M., Keller, B., Li, W., Mccombie, W.R., Ogihara, Y., Quetier, F. and Sasaki, T. (2004). A workshop report on wheat genome sequencing: International Genome Research on Wheat Consortium. Genetics, 104: 034769.

Gu, L., Si, W., Zhao, L., Yang, S. and Zhang, X. (2015). Dynamic evolution of NBS-LRR genes in bread wheat and its progenitors. Molecular Genetics and Genomics, 290: 727-738.

Habibzadeh, E., Keshavarzi, M., Afshari, F. and Naghavi, M.R. (2007). Genetic diversity and disease resistance genes variation co-evaluation in wheat by RGA molecular marker. Plant Diseases, 3: 327-337. (In Persian)

Jia, J., Zhao, S., Kong, X., Zhao, G., He, W., Appels, R., Pfeifer, M., Tao, Y., Zhang, X. and Li, Y. (2013). Aegilops tauschii draft genome sequence reveals a gene repertoire for wheat adaptation. Nature, 496: 91-95.

Jiang, H., Wang, C., Ping, L., Tian, D. and Yang, S. (2007). Pattern of LRR nucleotide variation in plant resistance genes. Plant Science, 173: 253-261.

Karakas, O., Gurel, F. and Uncuoglu, A.A. (2011). Assessment of genetic diversity of wheat genotypes by resistance gene analog-EST markers. Genetics and Molecular Research, 10: 10981110.

Kassa, M.T., You, F.M., Hiebert, C.W., Pozniak, C.J., Fobert, P.R., Sharpe, A.G., Menzies, J.G., Humphreys, D.G., Harrison, N.R., Fellers, J.P., McCallum, B.D. and McCartney, C.A. (2017). Highly predictive SNP markers for efficient selection of the wheat leaf rust resistance gene Lr16. BMC Plant Biology, doi: 10.1186/s12870-017-0993-7.

Leister, D., Ballvora, A., Salamini, F., and Gebhardt, C. (1996). A PCR-based approach for isolating pathogen resistance genes from potato with potential for wide application in plants. Nature Genetics, 14: 421-429.

Ling, H.-Q., Zhao, S., Liu, D., Wang, J., Sun, H., Zhang, C., Fan, H., Li, D., Dong, L. and Tao, Y. (2013). Draft genome of the wheat A-genome progenitor Triticum urartu. Nature, 496: 87-90.

Liu, J., Liu, X., Dai, L. and Wang, G. (2007). Recent progress in elucidating the structure, function and evolution of disease resistance genes in plants. Journal of Genetics and Genomics, 34: 765776.

Ma, J. (2015). Coordination of microRNAs, phasiRNAs, and NB-LRR genes in response to a plant pathogen: Insights from analyses of a set of soybean Rps gene near isogenic lines. Plant Gene, doi:10.3835/plantgenome2014.3809.0044.

Maestra, B. and Naranjo, T. (2000). Genome evolution in Triticeae. Chromosomes Today, 13: 155167. 
Mantovani, P., Van der Linden, G., Maccaferri, M., Sanguintei, M.C. and Tuberosa, R. (2006). Nucleotide-binding site (NBS) profiling of genetic diversity in durum wheat. Genome, 49: 14731480 .

Mace, E., Tai, S., Innes, D., Godwin, I., Hu, W., Campbell, B., Gilding, E., Cruickshank, A., Prentis, P. and Wang, J. (2014). The plasticity of NBS resistance genes in sorghum is driven by multiple evolutionary processes. BMC Plant Biology, 14: 253- 266.

McIntosh, R.A., Welling, C.R. and Park, R.F. (1995). Wheat rusts: an atlas of resistance genes. CSIRO Melbourne, Australia, p.p. 200.

O'Toole, N., Hattori, M., Andres, C., Iida, K., Lurin, C., Schmitz-Linneweber, C., Sugita, M. and Small, I. (2008). On the expansion of the pentatricopeptide repeat gene family in plants. Molecular Biology and Evolution, 25: 1120-1128.

Powell, W., Morgante, M., Andre, C., Hanafey, M., Vogel, J., Tingey, S. and Rafalski, A. (1996). The comparison of RFLP, RAPD, AFLP and SSR markers for gerplasm analysis, Molecular Breeding, 2: 225-238.

Reynolds, M., Moya, E.S., Molero, G., Vargas, M. and Payne, T. (2012). Germplasm evaluation and delivery. Proceedings of the $2^{\text {nd }}$ International Workshop of the Wheat Yield Consortium, 12-15 March 2012.CIMMYT, Mexico, D.F.

Richly, E., Kurth, J. and Leister, D. (2002). Mode of amplification and reorganization of resistance genes during recent Arabidopsis thaliana evolution. Molecular Biology and Evolution, 19: 76-84.

Roldain-Ruiz, I., Calsyn, E., Gilliand, T.J., Coll, R., van Eijk, M.J.T. and De Loose, M. (2000). Estimating genetic conformity between related ryegrass (Lolium) varieties. 2: AFLP characterization. Molecular Breeding, 6: 593-602.

Rommens, C.M. and Kishore, G.M. (2000). Exploiting the full potential of disease resistance genes for agricultural use. Current Opinion in Biotechnology, 11: 120-125.

Saghai-Maroof, M.A., Soliman, K., Jorgensen, R.A. and Allard, R.W. (1984). Ribosomal DNA spacer-length polymorphisms in barley: Mendelian inheritance/chromosome location and population dynamics. Proceeding of National Academic Science USA/ 81: 8014-8018.

Sekhwal, M. K., Li, P., Lam, I., Wang, X., Cloutier, S. and You, F. M. (2015). Disease Resistance Gene Analogs (RGAs) in Plants. International Journal of Molecular Sciences, 16: 19248-19290.

Shewry, P.R. (2009). Wheat. Journal of Experimental Botany, 6: 1537-1553.

Singh, S., Chand, S., Singh, N.K. and Sharma, T.R. (2015). Genome-wide distribution, organization and functional characterization of disease resistance and defense response genes across rice species. PLoS ONE, 10: e0125964.

Soriano, J. M., Vilanova, S., Llacer, C.R.G. and Badenes, M.L. (2005). Characterization and mapping of NBS-LRR resistance gene analogs in apricot (Prunusa rmeniaca L.). Theoretical Applied Genetics, 110: 980-989.

Tabassum, S., Ashraf, M. and Chen, X. (2010). Evaluation of Pakistan wheat germplasms for stripe rust resistance using molecular markers. Science China Life Sciences, 53:1123-1134.

Tamura, K., Dudley, J., Nei, M. and Kumar, S. (2011). MEGA 5: Molecular evolutionary genetics analysis (MEGA) software, version 5.0. Molecular Biology Evolution, 24: 1596-1599.

Wang, M., van den Berg, R., Van der Linden, G. and Vosman, B. (2008). The utility of NBS profiling for plant systematics: a first study in tuber-breeding Solanum species. Plant Systematics and Ecology, 276: 137-148.

Wang, S.S., Wang, F., Tan, S.J., Wang, M.X., Sui, N. and Zhang, X.S. (2014). Transcript profiles of maize embryo sacs and preliminary identification of genes involved in the embryo sac-pollen tube interaction. Frontiers In Plant Science, 5: 702-716.

Wei, H., Li, W., Sun, X., Zhu, S. and Zhu, J. (2013). Systematic analysis and comparison of nucleotide-binding site disease resistance genes in a diploid cotton Gossypium raimondii. PLoS ONE, 8, e68435.

Wise, R.P. (2000). Disease resistance: what's brewing in barley genomics? Plant Disease, 84: 11601170 . 


\title{
Diversity of Resistance Gene Analogues in Rust Resistance and Susceptible Bread Wheat Varieties
}

\section{Faranak Khanmakoo', Seyed Abolghasem Mohammadi ${ }^{2},{ }^{*}$, Robab Salami ${ }^{1}$ and Saeed Aharizad $^{2}$}

1- Former M.Sc. Student, Department of Plant Breeding and Biotechnology, Faculty of Agriculture, Tabriz University, Tabriz, Iran

2- Professor, Department of Plant Breeding and Biotechnology, Faculty of Agriculture, Tabriz University, Tabriz, Iran

(Received: April 18, 2017 - Accepted: January 11, 2018)

\begin{abstract}
Fungal diseases, especially leaf and stripe rusts are wheat yield reducing factors in Iran and the world. In this study, genetic diversity of 20 wheat varieties with different response to leaf and stripe rusts were studied using primers designed based on the conserved regions of plant disease resistance genes. The banding patterns of polymorphic markers were scored as dominant and number of amplified bands and percentage of polymorphism were determined. In addition, for each primer combination, polymorphic information content (PIC) and marker index (MI) were calculated. Out of the 11 used single primers and primer combinations, five primer combinations and a single primer produced scorable amplification. The maximum and minimum of PIC were observed for LLOOP-1 and H2016$\mathrm{H} 2020$ primer combination with mean value of 0.50 and 0.28 , respectively. The primer combinations of $\mathrm{H} 2016-\mathrm{H} 1146$ and $\mathrm{H} 2016-\mathrm{H} 2020$ with mean values of 4.80 and of 2.84, had minimum and maximum of MI, respectively. Cluster analysis based on Neighbor-Joining algorithm and evolutionary P-distance coefficient assigned the varieties into four groups which were in agreement with their response to yellow rust. In principal coordinate analysis, the scatter plot of varieties based on two first coordinates confirmed the groups obtained from cluster analysis.
\end{abstract}

Keywords: Resistance gene analogues, Genetic diversity, Yellow rust, Leaf rust

\footnotetext{
*Corresponding Author, E-mail: mohammadi@ tabrizu.ac.ir
} 